\title{
Mark Whittow \\ 24 August 1957 to 23 December 2017
}

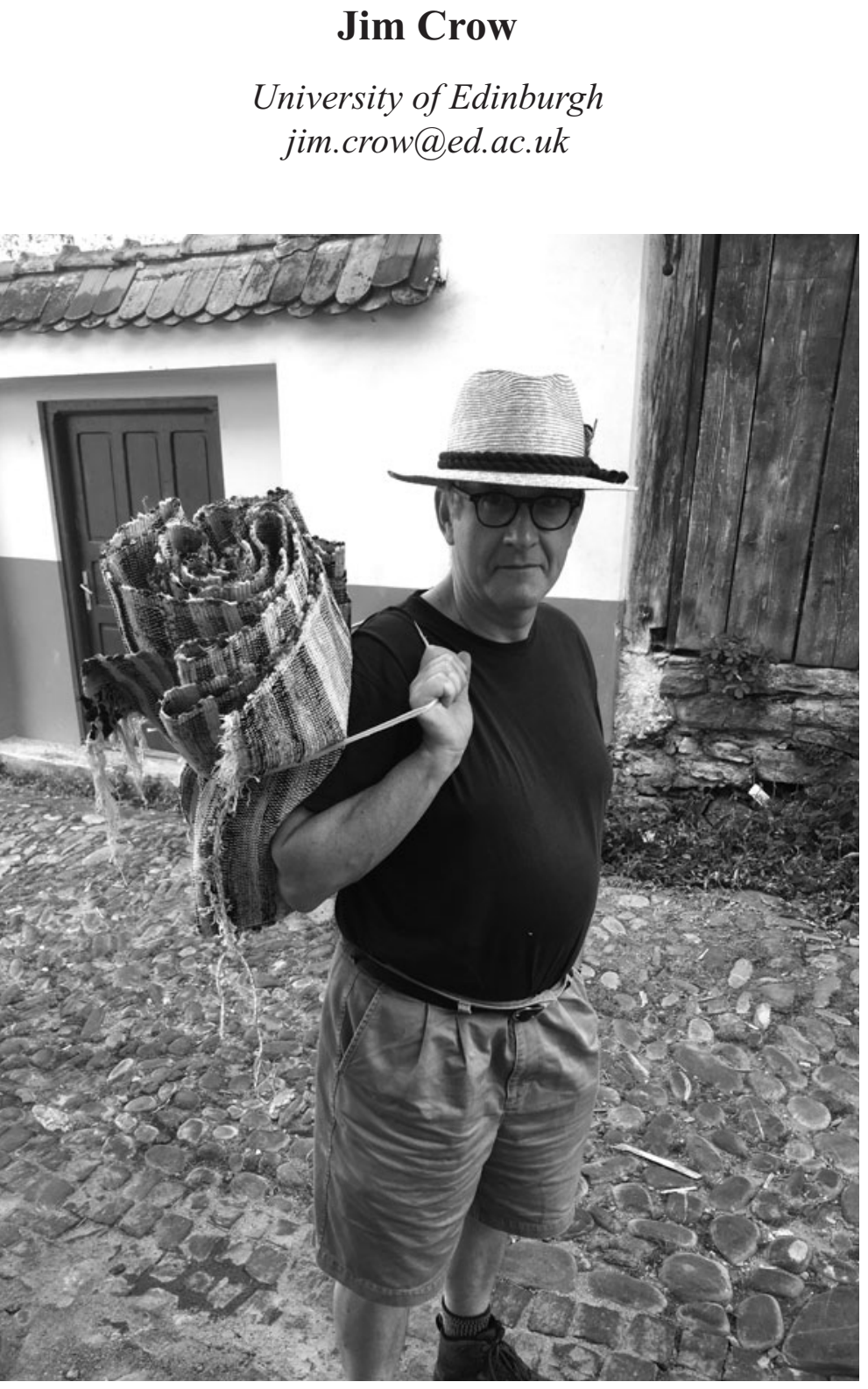

$\mathrm{A}$

mongst the acknowledgements of an article on the late Roman local economy, published in 2013, is an apology to the Fellows of Corpus Christi College for the late appearance of The Pelican Record. Mark Whittow was both the editor of the College's annual record and the author of the article teasing out yet further details on the late Roman economy through insightful comparisons across medieval history ranging from early medieval Italy to England after the Black Death. His death in a road accident shortly before Christmas 2017 at the age of 60 is a great loss to Byzantine studies and to the wider academic community, especially at Oxford.

He was not just another medieval historian. As an undergraduate he studied Modern History at Oxford and went on to research a DPhil on Social and Political Structures in the Meander Regions of Asia Minor on the Eve of the Turkish Invasion, completed in 1987. The postdoctoral monograph had to wait, and, instead, in 1990 he 
was able to publish in Past and Present a virtuoso study on 'Ruling the late Roman and early Byzantine city: a continuous history', combining the results of archaeological research with a clear grasp of the complexities of late Roman administration at a local level.

He held a number of short-term lectureships before his appointment as Fellow at St Peter's College, Oxford in 1997 and his later transfer to Corpus Christi College when he became University Lecturer in Byzantine Studies in 2010. In 2016-2017 Mark served as the university's Senior Proctor and had been appointed to take up the position of Provost of Oriel College in September 2018.

The early years were well spent, and in 1996 he published his great work The Making of Orthodox Byzantium, 600-1025. For some Byzantinists he does not display sufficient attention to the doctrinal controversies of the age; but, as one obituarist has observed, Christianity, was not - as Gibbon would have had it - a great corrosive of society, but rather, in Mark's words, 'a useful morale booster'. The book remains one of the clearest and most reliable guides to this extremely difficult period in history. In all his writings he displays an exceptional awareness of the geographical context of world events and, most recently, he was the area advisor for Asia Minor for the new Oxford Dictionary of Late Antiquity (2018).

After his initial research in the Meander valley, at the suggestion of David French he set up a project to continue the British Institute at Ankara's programme of recording the medieval castles of Anatolia, originally initiated by Clive Foss. In all there were four seasons (1992-1996) in partnership with Hugh Barnes. Preliminary publications appeared in Anatolian Studies 43 (1993) and 44 (1994), and an overview in the Institute's Fifty Years' Work volume, edited by Roger Matthews. Both of the preliminary publications are of particular interest, not just for the detailed plans and site descriptions but also because Mark is not shy to reveal the changing interpretations required to make sense of surveyed walls and landscapes, as well as to reach out for comparanda from medieval Europe, including Islamic Spain.

During the years of the 'Castles Project' he was a member of the Institute's Council of Management and he later became involved with the administration of the Council for British Research in the Levant. His love of fieldwork did not end and he participated in a season of Roger Matthews' Project Paphlagonia. But research was only one part of his academic life and it is clear that teaching, tutorials and lectures meant as much, if not more to him. This concern is apparent in his writings and in his willingness to continue to present outstanding syntheses such as chapters on the late Roman Empire in the East in the New Cambridge History of Islam or on the Byzantine economy in the Cambridge History of the Byzantine Empire.

But above all, we will miss his evident enjoyment of life and his honest fairness and moderation as a teacher and scholar. 